\title{
Infiltrating Bladder Urothelial Carcinoma
} Sarcomatoid Variant

National Cancer Institute

\section{Source}

National Cancer Institute. Infiltrating Bladder Urothelial Carcinoma Sarcomatoid Variant. NCI Thesaurus. Code C39824.

An invasive transitional cell carcinoma of the bladder that exhibits spindle cell sarcomatoid features. 